\title{
PENINGKATAN KOMPETENSI GURU MENERAPKAN TEKNOLOGI INFORMASI DAN KOMUNIKASI DALAM PROSES PEMBELAJARAN MELALUI SUPERVISI AKADEMIK
}

\author{
ASMAN BANDERA \\ MTsN 1 Buton Tengah, Sulawesi Tenggara \\ Email : asman.bandera@yahoo.com
}

\begin{abstract}
ABSTRAK
Penelitian ini bertujuan untuk mengetahui (a) pengaruh Peningkatan Kompetensi Guru Menerapkan TIK Dalam Proses Pembelajaran Melalui Supervisi Akademik dan (b) aktivitas guru kelas dalam menggunakan media tekhnologi komunikasi informasi, digunakan metode penelitian tindakan sekolah (PTS) dengan dua siklus yang masing-masing siklusnya terdiri dari tahap (1) perencanaan, (2) pelaksanaan tindakan perbaikan, (3) observasi, dan (4) refleksi. Hasil penelitian menunjukkan bahwa (a) terjadi peningkatan kompetensi guru dalam menerapkan TIK Melalui Supervisi Akademik Pada Guru Kelas Madrasah Tsanawiyah 1 Buton Tengah Sulawesi Tenggara. Penilaian melalui Rubrik Penilaian Rencana Pelaksanaan Pembelajaran pada siklus 1 yang mencapai nilai 119, berada pada katagori baik, dan hasil penilaian pada siklus kedua yang mencapai nilai 151, berada pada katagori sangat baik, dan (b) aktivitas guru dalam pelaksanaan pemebelajaran pada siklus kedua lebih baik daripada pada saat siklus kesatu. Penilaian melalui Rubrik Penilaian Aktivitas Guru dalam proses pembelajaran selama pada siklus kesatu yang mencapai nilai 30 atau tergolong baik, dan pada sikulus kedua mencapai nilai 36, yang berati tergolong sangat baik. Dimana hasil akhir yang diperoleh dari Siklus I skor 119 dan Siklus II skor 151 dalam penelitian ini dengan prosentase naik $25,8 \%$ adanya peningkatan.
\end{abstract}

Kata Kunci: Kompetensi Guru, TIK, Supervisi Akademik

\section{PENDAHULUAN}

Lingkungan pendidikan adalah segala sesuatu yang ada di sekitar manusia, baik berupa benda mati,makhluk hidup ataupun peristiwa-peristiwa yang terjadi termasuk kondisi masyarakat terutama yang dapat memberikan pengaruh kuat kepada individu. Seperti lingkungan tempat pendidikan berlangsung dan lingkungan tempat anak bergaul. Lingkungan ini kemudian secara khusus disebut sebagai lembaga pendidikan sesuai dengan jenis dan tanggung jawab yang secara khusus menjadi bagian dari karakter lembaga tersebut.

Perubahan lingkungan luar dunia pendidikan, mulai lingkungan sosial, ekonomi, teknologi, sampai politik mengharuskan dunia pendidikan memikirkan kembali bagaimana perubahan tersebut mempengaruhinya sebagai sebuah institusi sosial dan bagaimana harus berinteraksi dengan perubahan tersebut. Salah satu perubahan lingkungan yang sangat mempengaruhi dunia pendidikan adalah hadirnya Teknologi, Informasi dan Komunikasi (TIK).

Dalam menyoroti salah satu peran guru dalam proses pembelajaran, yaitu sebagai perencana pembelajaran, setiap guru pada satuan pendidikan, termasuk guru kelas berupaya meningkatkan kompetensi TIK agar pembelajaran efektif dan bermutu. Pembelajaran yang berlangsung secara efektif dan bermutu akan berimplikasi pada peningkatan mutu proses dan hasil belajar peserta didik.

Guru MTsN 1 Buton Tengah telah melaksanakan proses belajar mengajar dengan didukung TIK. Namun masih ditemukan berbagai kekurangan baik menyangkut persiapan sebelum pelaksanaan proses belajar mengajar, dalam penyusunan RPP. Kekurangan yang pertama sebelum penyusunan RPP adalah sebagaian besar guru tidak Sebagian besar guru tidak menentukan kriteria ketuntasan minimal KKM dan sebagian guru tidak membuat sendiri silabus mata pelajaran. 
Kekurangan yang kedua saat penyusunan RPP adalah sebagian besar guru kurang menjelaskan apa yang dilakukan siswa selama berlangsungnya pembelajaran dalam rencana kegiatan pembelajarannya, sebagian besar guru tidak menjelaskan sumber belajar dengan rinci, sebagian besar guru tidak menjelaskan (1) bentuk instrumen evaluasi, (2) format / lembaran evaluasi atau butir soal (free test dan post test), (3) pedoman penilaian, dan kunci jawaban, dalam evaluasi proses dan hasil belajar siswa. Sebagaian besar guru tidak merencanakan tindak lanjut setelah selesai pembelajaran (pembelajaran remedial, program pengayaan, layanan konseling atau tugas individu / kelompok) dalam kaitan antara KKM mata pelajaran dengan nilai yang dicapai siswa. Kekurangan yang ketiga saat pelaksanaan pembelajaran adalah Sebagian besar guru tidak berpedoman sepenuhnya pada RPP dalam pelaksanan pembelajarannya. Semua itu terkait dengan kondisi di lapangan bahwa : (a) Semua guru kelas tidak berlatar belakang pendidikan TIK, (b) banyaknya guru kelas yang hanya kompeten dalam cabang pelajaran tertentu yang bukan TIK, (c) tidak semua guru kelas, terutama yang berstatus honorer, berkesempatan mengikuti penataran atau diklat TIK, (d) jarangnya kegiatan KKG TIK kabupaten Brebes yang khusus membahas TIK tersebut.

Kondisi yang demikian menjadikan persepsi guru kelas mengenai ICT yang harus dikuasai sebelum melaksanakan pembelajaran di kelas, studio atau tempat belajar lainnya menjadi kurang dikuasi. Misalnya masih terdapat guru yang belum memahami operasi computer dan infoku, apalagi mengenai Internet. Kekurangan ini tentu saja akan menghambat upaya peningkatan mutu proses dan hasil pembelajaran Guru Kelas , karena kompetensi-nya tidak dikuasai dengan baik. Padahal, keberhasilan sebuah kegiatan, lebih dari 50\% ditentukan oleh kompetensi yang baik, sehingga keberhasilan pembelajaran pun amat ditentukan oleh kompetensi guru. Dengan memahami kondisi yang demikian, maka dipandang perlu adanya Peningkatan Kompetensi Guru Menerapkan TIK Dalam Proses Pembelajaran Melalui Supervisi Akademik MTsN 1 Buton Tengah, Sulawesi Tenggara.

\section{METODE PENELITIAN}

Penelitian Tindakan Sekolah ini dilaksanakan di MTsN 1 Buton Tengah, Sulawesi Tenggara. Alasan pemilihan MTsN 1 Buton Tengah, Sulawesi Tenggara karena peneliti adalah kepala sekolah di Madrasah Tsanawaiyah tersebut. Dengan demikian akan memperlancar pelaksanaan penelitian. Subyek penelitian ini adalah Guru MTsN 1 Buton Tengah, Sulawesi Tenggara. Metode yang digunakan dalam penelitian ini adalah metode Penelitian Tindakan Sekolah (PTS). PTS merupakan suatu prosedur penelitian yang diadaptasi dari Penelitian Tindakan Kelas (PTK). Secara singkat, PTS bertujuan untuk mencari pemecahan permasalahan nyata yang terjadi di sekolah-sekolah, sekaligus mencari jawaban ilmiah bagaimana masalah-masalah tersebut bisa dipecahkan melalui suatu tindakan perbaikan.

Masalah nyata yang ditemukan di sekolah, khususnya pada guru kelas adalah belum optimalnya dalam menyusun RPP walaupun dari segi implementasi menggunakan TIK. Prosedur penelitiannya dilakukan secara siklikal. Satu siklus dimulai dari (1) perencanaan awal, (2) pelaksanaan, (3) observasi dan (4) refleksi.

1. Perencanaan, Yaitu membuat rencana perbaikan berdasarkan adanya masalah atau kondisi yang menuntut diperbaiki.Hal ini meliputi persiapan bahan-bahan yang diperlukan dalam tahap pelaksanaan,menentukansiapa (subyek penelitian dan teman berkolaborasi), kapan (jadwal pelaksanan), dan tempat pelaksanaan; 2. Pelaksanaan (Action), Yaitu melakukan tindakan substantif penelitian melalui intervensi skala kecil guna memperbaiki kondisi yang diteliti; 3 . Observasi (Observation), Yaitu kegiatan mengamati, mengenali sambil mendokumentasikan (mencatat dan merekam) terhadap proses, hasil, pengaruh dan masalah baru yang mungkin saja muncul selama proses pelaksanaan tindakan; 4. Refleksi (Reflection), Yaitu melakukan renungan, kajian reflektif diri secara inquiri, partisipasi diri (partisipatoris),kolaborasi terhadap latar alamiah 
dan impiikasi dari suatu tindakan, dengan melakukan analisis terhadap rencana dantindakan yang sudah dilaksanakan dan hasil yang dicapai, dan apa yang belum dapat atau sempat dilakukan. Untuk lebih jelasnya bisa dilihat pada gambar bagan dibawah ini :

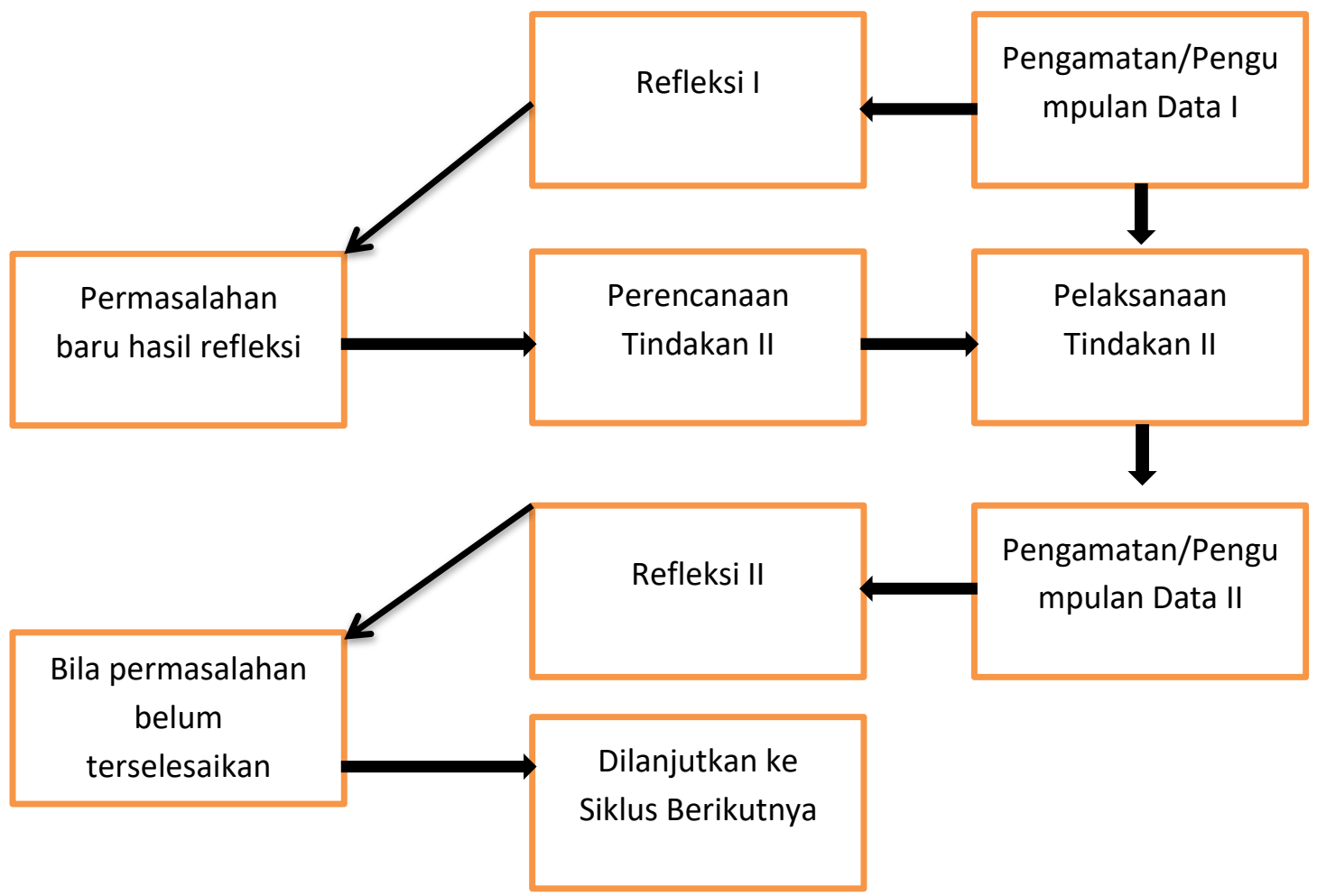

Gambar 1. Langkah-langkah PTS

Hasil dari siklus pertama ini menjadi masukan bagi pelaksanaan siklus kedua yang terdiri dari perulangan keempat langkah yang ada pada siklus pertama. Hal ini terjadi karena dimungkinkan setelah melalui siklus pertama, peneliti menemukan masalah baru atau masalah lama yang belum tuntas, sehingga perlu dipecahkan melalui siklus selanjutnya.

Dalam penelitian ini instrumen yang digunakan untuk mengumpulkan data adalah lembar observasi berupa rubric, Wawancara, Studi Dokumenter dan Studi Pustaka. Rubrik ini diisi oleh peneliti melalui pangamatan sebelum, pada saat, dan sesudah proses penyusunan RPP. Hasilnya digunakan untuk menentukan tindakan selanjutnya.

\section{HASIL DAN PEMBAHASAN}

Sebelum melakukan tindakan perbaikan, peneliti terlebih dahulu melakukan kegiatan orientasi sebagai studi pendahuluan. Dalam kegiatan ini guru "didiagnosis" sehingga peneliti menemukan derajat kelengkapan dan kesistematisan RPP yang disusun guru pada saat awal kegiatan mengajar. Peneliti mengamati aktivitas guru dalam persiapan dan selama proses penyusunan RPP, kemudian mengevaluasi RPP yang dibuatnya. Hasil pengamatan dan evalusi tersebut kemudian dijadikan bahan untuk mencari upaya perbaikan (tahap tindakan) pada siklus penelitian. Prakteknya, guru-guru diminta menyusun secara spontan tanpa ada intervensi atau berlangsung alami seperti yang mereka lakukan sehari-hari sebelum mengajar.

Dengan menggunakan Rubrik Penilaian Aktivitas Guru Kelas Dalam Peningkatan Kompetensi Guru Menerapkan TIK dalam proses Pembelajaran Melalui Supervisi Akademik. 
Tabel 1. Rekapitulasi pada Rubrik Skor Kemampuan Guru Kelas Siklus 1

\begin{tabular}{|c|c|c|c|c|}
\hline \multirow[t]{3}{*}{ No } & \multirow{3}{*}{$\begin{array}{l}\text { Nama } \\
\text { Guru }\end{array}$} & \multicolumn{3}{|c|}{ Skor Penilaian } \\
\hline & & Persiapan & Aktivitas Guru Dalam & Penilaian \\
\hline & & $\begin{array}{l}\text { Penyusunan } \\
\text { RPP }\end{array}$ & Proses Pembelajaran & RPP \\
\hline 1. & VII & 5 & 29 & 110 \\
\hline 2. & VIII & 7 & 31 & 128 \\
\hline Jum & & 12 & 60 & 238 \\
\hline Rat & & 6 & 30 & 119 \\
\hline
\end{tabular}

Dari Tabel 1 dapat dilihat, tentang Aktivitas Guru Kelas, Proses Penyusunan RPP, Proses Pembelajaran dan Penilaian RPP setelah di implementasikan pada Siklus 1 adalah sebagai berikut untuk Persiapan Penyusunan RPP pada Siklus 1 mencapai nilai 6 Rencana Pelaksanaan Pembelajaran pada siklus 1 yang mencapai nilai 119, berada pada katagori baik, Penilaian melalui Rubrik Penilaian Aktivitas Guru dalam proses pembelajaran selama pada siklus kesatu yang mencapai nilai 30 atau tergolong baik.

Tabel 2. Rekapitulasi pada Rubrik Skor Kemampuan Guru Kelas Siklus 2

\begin{tabular}{|c|c|c|c|c|}
\hline \multirow[t]{3}{*}{ No } & \multirow{3}{*}{$\begin{array}{l}\text { Nama } \\
\text { Guru }\end{array}$} & \multicolumn{3}{|c|}{ Skor Penilaian } \\
\hline & & $\overline{\text { Persiapan }}$ & Aktivitas Guru Dalam & Penilaian \\
\hline & & $\begin{array}{l}\text { Penyusunan } \\
\text { RPP }\end{array}$ & Proses Pembelajaran & $\mathrm{RPP}$ \\
\hline 1. & VII & 7 & 35 & 147 \\
\hline 2. & VIII & 9 & 37 & 155 \\
\hline Jun & & 16 & 72 & 302 \\
\hline$\overline{\mathrm{Rat}}$ & & 8 & 36 & 151 \\
\hline
\end{tabular}

Penilaian melalui Rubrik Penilaian Rencana Pelaksanaan Pembelajaran pada siklus 2 yang mencapai nilai 151, berada pada katagori sangat baik, dan (b) aktivitas guru dalam pelaksanaan pemebelajaran pada siklus 2 lebih baik daripada pada saat siklus 1. Penilaian melalui Rubrik Penilaian Aktivitas Guru dalam proses pembelajaran selama pada siklus kedua mencapai nilai 36, yang berarti tergolong sangat baik.

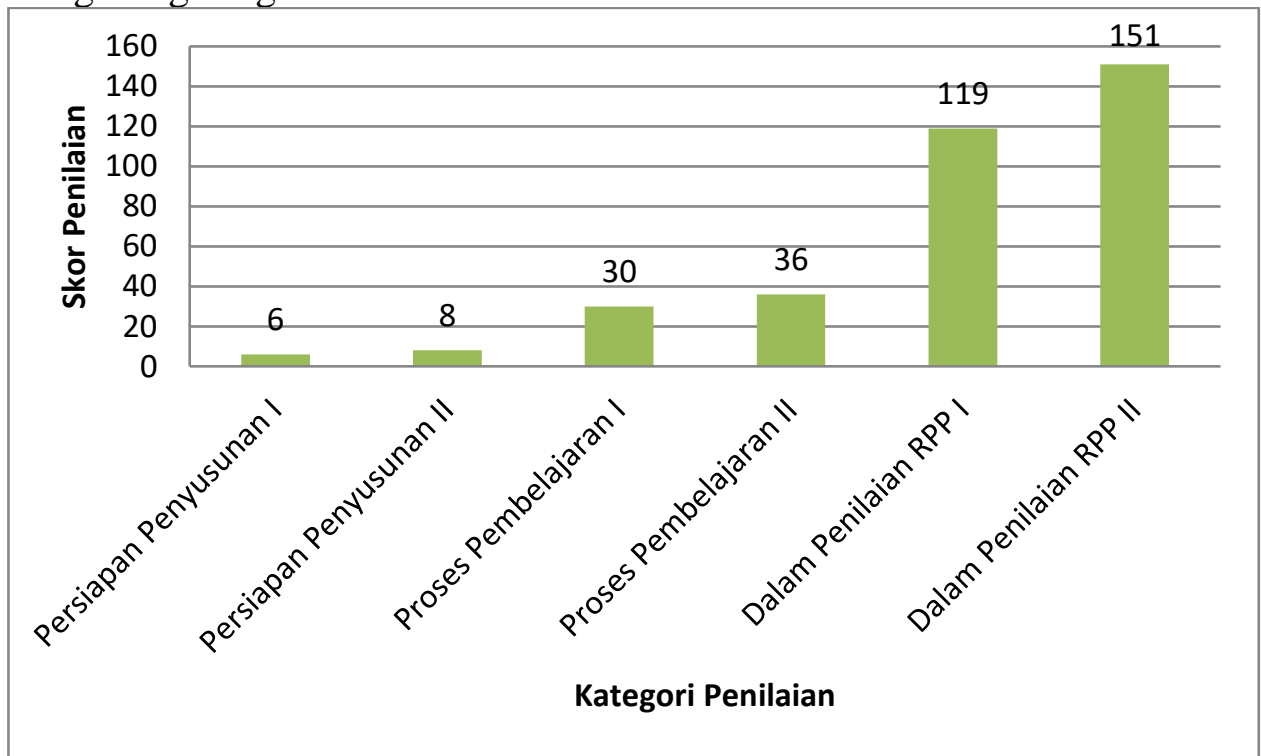

Grafik 1. Perbandingan Skor Siklus I dan Siklus II 
Berdasarkan hasil pelaksanaan tindakan kedua dapat kita ketahui bahwa adanya perubahan yang signifikan terjadi antara lain guru mencantumkan komponen Identitas dengan segala rinciannya dengan benar. Guru mencantumkan standar kompetensi (SK) yang sesuai dengan standar isi dan silabus. Guru mencantumkan kompetensi dasar (KD) yang sesuai dengan standar isi dan silabus. Guru mencantumkan komponen Indikator Pencapaian dengan rumusan kalimat yang mengandung kata kerja operasional yang terukur sebagai penjabaran kompetensi dasar, dan sesuai dengan materi pembelajaran. Guru mencantumkan komponen Tujuan Pembelajaran dengan kalimat yang mencantumkan subyek belajar (learner), target yang dicapai siswa, dan relevan dengan kompetensi dasar (KD) Guru mencantumkan komponen Materi Pembelajaran dengan rincian yang sistematis, sesuai dengan tujuan pembelajaran (TP) dan standar isi, dan telah mencantumkan materi pembelajaran untuk pengayaan.

Guru mencantumkan komponen Kegiatan Pembelajaran, membaginya kedalam Kegiatan Pembelajaran Pendahuluan, Kegiatan Pembelajaran Inti dan Kegiatan Pembelajaran Penutup. Setiap bagian dirinci menjadi kegiatan pembelajaran yang student centered, disertai alokasi waktu tiap kegiatan siswa. Guru mencantumkan komponen Metoda / Model Pembelajaran yang disatukan secara sistematis dengan komponen Kegiatan Pembelajaran. Guru dapat mencantumkan komponen Media / Sumber Pembelajaran dengan menentukan jenis sumber belajarnya sesuai dengan tuntutan kurikulum (kompetensi dasar dan silabus), tujuan pembelajaran, dan bentuk evaluasi. Guru mencantumkan komponen Penilaian (Evaluasi) Proses dan Hasil Pembelajaran, dan merincinya dengan lengkap, dari mulai bentuk evaluasi, menyertakan lembaran / format instrumen penilaian (butir soal, rubrik, dll.), pedoman penilaian, dan kunci jawabannya. Hasil observasi melalui Rubrik Penilaian Rencana Pelaksanaan Pembelajaran (RPP), nilainya mencapai nilai 151, yang berarti berada pada katagori sangat baik. Hasil observasi melalui Rubrik Penilaian Aktivitas Guru dalam Menyusun Rencana Pelaksanaan Pembelajaran (RPP) selama Kegiatan Supervisi, nilainya mencapai nilai 36 , yang berati berada pada katagori sangat baik.

\section{KESIMPULAN}

Simpulan dari hasil penelitian yang peneliti sajikan dalam Penelitian Guru MTsN 1 Buton Tengah ini sebagai berikut pertama pembinaan berkelanjutan melalui supervisi akademik yang dilakukan oleh Kepala Guru MTsN 1 Buton Tengah dapat meningkatkan kemampuan guru dalam melaksanakan Proses Pembelajaran dengan menggunakan Teknologi, Informatika dan Komunikasi yang disertakan dengan Administrasi sebagai guru salah satunya Penyusunan RPP, Hal ini dapat diketahui dalam hasil penelitian dari jumlah skor kondisi awal 119 menjadi 151. Jadi peningkatannya sebesar $25,8 \%$. Kedua pembinaan berkelanjutan dapat meningkatkan motivasi guru dalam menyusun perencanaan pembelajaran dengan menggunakan TIK.

\section{DAFTAR PUSTAKA}

BSNP. (2007). Peraturan Menteri Pendidikan Nasional Republik Indonesia Nomor 16 Tahun 2007 Tentang Standar Kualifikasi Akademik dan Kompetensi Guru. Jakarta : BSNP.

Depdiknas. (2003). Revitalisasi Musyawarah Guru Mata Pelajaran (MGMP). Jakarta : Program Pendidikan Menengah Umum.

Depdiknas. (2008). Pedoman Penelitian Tindakan Sekolah (School Action Research) Peningkatan Kompetensi Supervisi Pengawas Sekolah Jakarta : Dirjen PMPTK.

Makmun, Abin Syamsudin. (2005). Psikologi Kependidikan, Perangkat Sistem Pengajaran Modul. Bandung : PT. Remaja Rosdakarya.

Panitia Pelaksana Pendidikan dan Latihan Profesi Guru Rayon 10 Jawa Barat. (2009). Bahan Ajar Pendidikan dan Latihan Profesi Guru (PLPG), Pengawas. Bandung : Universitas Pendidikan Indonesia. 
Peraturan Menteri Pendidikan Nasional Republik Indonesia Nomor 41 Tahun 2007 Tentang Standar Proses untuk Satuan Pendidikan Dasar dan Menengah.

Peraturan Pemerintah Nomor 19 Tahun 2005 tentang Standar Nasional Pendidikan. Sagala, H. Syaiful. (2006). Administrasi Pendidikan Kontemporer. Bandung : Alfabeta. 